\title{
FOREIGN NEWS
}

\author{
1\% Cllargi; OF
}

LAVINIA L. DOCK

\section{ORGANIZATION NOTES}

\section{THE NATIONAL LEAGUE OF CERTIFICATED NURSES OF GREAT BRITAIN AND IRELAND}

WE would like to eall the attention of our organized nurses apecially to the moyement now going on in England, fostered ly the Matrons' Comeil, for laying the foundations of a general union of nurses organizations. The greneral plan and purposes are rery similas to those of our Associated Alumure. Local selfgoverning groups of umses are to send their delegates to a central national body, which nay thus, in time, represent the entire mursing profession. and affiliation with the Matrons' Comneil is looked for, just as wo lave afliliated in this conutry with the superintendents' Sociey.

We eanuot donbt that this is the strongest possible way in which to organize ourselves if we wish ever to make onr mited influnce felt,-local self-goverument and independence, friendly co-operation and foderation with of her local bodies, and intermatimal mion. Alrobly the British Jslands have two gromps of over four humdred members each realy to combine,-St. Bartholomew's leagne, corresponding to our Almmux Associations, and the Dublin Nurses' Club, corresponding to our general associations. The Constitution of the Englisl National society is given as follows:

\section{ARTICLE I.-NAME.}

The name of this association slatl be "The Xatimal beagne of Cortitiented Nurses of Great Britain and Jreland."

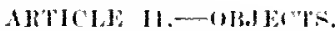

The oljeets of the National feagne sloall be:

1. To establish and maintain a Corle of Lithies.

2. To rlevate the stambard of nursing education.

3. To promote the nsefuness and honor, the financial and other interests of the nursing profession.

AITICIE III-- ET.JGHHITTY.

Associations of nurses having the following qualifications slatl be cligilale for afliliation witl the National Jeagne:

1. Associations eomposed of graduates of selools of nursing commeted with general hospitals of not less than fifty beds, giving there years full training in the wards of the hospital and certification after examination.

2. Associations composed of graduates of schools of nursing connected with Poor Jaw infirmaries of not less than two hundred beds, giving three years' full training in the warls of the infirmary and certifieation after exumination, and whose training-selools are recognized by the Loeal Governuent Board.

3. Profossional atsociations of nurses, formed for the benefit of nurses, the mombers of which boll the qualifieations of training as defined abow. 
ARTICLE IV.-MEMBERSIIP.

Memberslip of the National League slatl be confined to trained nurses as defined above, and divited into members, active menbers, and honorary members. Members shall consist of all members of the aflitated associations. Aetive members shatl consist of delegates duly eleeted to represent these associations on the Grand Comneil of the National League, and shall include all homorary officers of the National leagne. Ifonorary members shall eonsist only of murses who have rendered distinguished service to the nursing professiom.

ARTICIN V.-OFFICERS.

'The homorary oflieers of the National League shall be a president, first and second viec-presidents, secretary and treasurer, who shall be ex-oficio menbers of all committees.

ARTICLF VI.-GOVERNAIENT.

Grand Council.

1. The National League shall be governed by a Grand Couneil eomposed of duly appointed delegates from affiated associations and the homornly oflicers.

9. Societies affiliated to the National League shall lave the right to representation by delegation on the Grand Comicil as follows: Each assoeiation of moler a lindred members shall have the right to depnte one delegate; over one hmudred, and up to three hondred members, two delegates; and over throe hundred members, three delegates, after which there shall be no increase of representation.

3. The Grand Conncil shall meet annually for the transaction of business, when the honorary oflicers, who shall form the Execntive Committee, shatl be elected.

\section{Exceutive Commiltec.}

The Executive Committee shall be emposed of the homorary oflieers. It shall meet from time to time for the transaetion of business, and slall report anmally to the Grand Couneil.

ARTICLE VII,-CODE OF ETHICA,

The Cole of Ethies of the National League shall be binding upon all members.

ARTICl: VIJT-AMENDMENTS,

No addition or amendment shall be made to the Constitulion at an annual meeting muless such atdition or amendment be formally proposed and seconted by members of the National Leagne at the said meeting, nor mless notice shatl have been given in writing to the secretary of the full text of the proposed resolution by registered letter at least thee weeks previously for insertion npon the Agenda of the said meeting. Such addition or amendment must be carried by a majority vote of two-thirrls of those present at the necting.

\section{DUBLIN METROPOLITAN TECHNICAL SCHOOL, FOR NURSES.}

Tue ammal meeting of the governing body of the above school was held last woek, Mr. Ball presiding. The anmual report showed that fifty-one candidates from the different coinperating hospitals were sent up for examination in general elueation. 1)r. E. MeDowel Cosgrave delivered seventeen lectures on anatomy, physiology, and hygiene, and three demonstrations in invalid cookery were given at the National Training-Selool, kildare Street. There wore one 
thomsand one hundred and seventy attendanees at the lectures. The highest mumber of marks were gained by Miss Carrothers, of Sir Patrick Dmis llospital. to whom a silver medal was awarded. Miss Hessian, of the Richmomt lispital, gained the bronze medal.

\section{THE "NURSING RECORD" PEEPS INTO FUTURITY}

OUn English contemportry. the Nursing Record, has a helpful custom of giving at the end of the year a resume of nursing history and progress up to date. lts summary for the past year in the issue of Decewber 29 is especially full and vahable for referenes, beginning with the reform movements initiatel by Mrs. Fry, the Flidners, St. Johr's House, and Florenee Nightingale, giving all the important data from that time down to the present day, including the movements towards organization, the army unrsing agitation, edneational advances, and work of special distinction done by individnals. and eoneluding with a "Peep" into Futurity," whieh we would like to quote in full, did not lack of space forbir nore than the following brief extract:

\section{A PEEP INTO FUTURTT.}

"What will the new century bring us? Mlay we rentmre upon a forecast? lin the first place, it requires no prophet to tell us that there will be a great consolidation of one fores. The great luternational Nursing Congress at Buffalo next year, to which many of ns are looking forward, eamot fail to impress upon those who take part in it the many interests which murses of all lands have in common with one another, and to strengthen the bonds of fellowship which already unite ns. We believe that the new century will be remitrulule for progress in the more eflicient education of murses, and we look forwarl, tirst of all, to politieal enfanchisement for womrn, beease we are beeming inerensingly clombtful whother any profession of women, onr own ineluded, will make muel headway until we have obtained this fundanental basis of freedom.

"And then what vistas open up before us! Our own profession will be recmited from the ratuks of women inspired with a solse of their responsibility to the state and of their duty as law-makers as well as law-kecpers. With this power will surely cone to unrses the desire for the best form of professional efhcation, and we shall see order arising out of ehaos, symmetry evolving from confusion. A minimum enrrieulum of edueation will be laid down, and we foresee that the probationer of the future, in common with the aspirants for all other professions, will have to prohnee evilence of general edneation from some $\mathrm{xam}$ ining edueational boly. Then only will she be eligible for preliminary training for her chosen work in the College of Nursing which will then cxist, not only in Areams, but in solid masonry, Its elass-rooms will be hives of busy industry, where sweet-voiced professors of the seience of mursing. whos. experience has been gained by praetieal work, will leeture.

"If the embryo probationer sueceds in satisfactorily passing throngh this preliminary training, then she will pass on to her praetical work in the hospital warl. Hor examiuation prior to obtaining its covetel diploma of nursing will also be condueted by examiners appointed by the college, and without this diploma no one will be recognized by the State as a trained murse. . . And is it not possible that the College of Nursing will not only be an echeational centre to murses during their undergraduate eareer, but that elases will also be a rrauged for graduate nurses, so that they may perfeet themselves in the special branches of their profession and so gradualy add to their qualifications?". 
The article closes with a plea for the extension of normal-school methods in the elueation of would-be nursing teaelers, and the whole ideal, though pitched high, is not more diffieult of realization than what has actually been done in the past hundred yeurs.

TuE sixiythird yearly report of Kaiserswertl, the venerable mother-honse of modem nursing, sent to us by the kindness of Pastor Zoellner, contains a deeply interesting account of the eelebration of the one Inmdredth birthday of Pastor 'Theodore Fliedner on January 2I, just one year ago. Although invitations to the anniversary festival were limited to the deaconess establishments and afliliated institutions foumled by Fliedner and to the old friends who were left of his first. Sisters and tenehers, the memorials were widely alluded to thronghout Germany in the press and pulpit. and, best of all, the means neessary to build and maintain a home hospital for the sick and worlont Sisters were given as a tribnte to the labors of these self-denying women. Only one eriticisul we make as to the reports of the kitiserswertl work,--little or nothing is ever said as to the part taken by llother Fliednes. When will her biographer arise to do her full honor?

\section{LETTERS}

\section{FROM OUR CORRESPONDENT IN ITALY}

(Continued from January number)

Ospridate Chinico, Naples.

Perhaps you will realize what is required of me when I tell you that, no nurse is allowed to remain in the four warls mless I am walking the hospital and making mysolf as ubiquitons as possible. If I go upstairs to lunch or to rest for more than a few minntes, I must colleet my floek, no matter what they are doing, and take them with me. . . The nurses leave the hospital between two and three P.M. and return to their homes. After they are gone I spend the aftcruon and evening in writing 11 , all the motes of the day's lecture for them to eopy. Thongh my pupils are fully up to the standard of the average English girl, they are too inexperined to take down eorretly the seientifie and teehnieal lectures, and this is better than revising all their written notes would be.

I wrote ont at the begrinning of the year a programme of the suljeets 1 considered necessary for nnrses, eopied from my .J. Il. Il, notes. The chief, whose ideas on uursing matters do not differ grealy from those prevalent in English hospitals, agreed with me. The leeturers, however, cularged a good deal on theory and technieality. In the course of the year they have realized that we need simple finets.

I put my murses into uniform in Febrnary. The material is rough ginglam, striped hue and white, with turn-down collars, high white aprons, and hemstitehed half-sleeres. Caps wonld have been against the ideas of propriety here, and I did not suggest them. With regard to ward work: during the first few months I was obligrol. not having any graduates, to leave three ont of the four wards to the servints and give my praetical lessons in the fourth. After six months training 1 was able to pnt the nurses in elarge of the wards, always under my direct snrveillance, of course, and the results have been such that the wird doctors are fully persuaded of the valne of our institution. 